\section{ANNIVERSARY OF THE ROYAL}

\section{GEOGRAPHICAL SOCIETY}

THE Anniversary Meeting of the Royal Geographical Society was held in the theatre of London University on Thursday, the Right Hon. Lord Aberdare, F.R.S., President, in the chair. In his address, Lord Aberdare referred to Mr. Keltie's report on the position of geographical education in England and on the Continent. The Report, Lord Aberdare stated, contains statements and recommendations of the highest interest and importance. Of the state of geographical education in Great Britain Mr. Keltie draws a very dismal picture. "There is no encouragement to give the subject a prominent place in the school curriculum; no provision, except at elementary normal schools, for the training of teachers in the facts and principles of the subject, and in the best methods of teaching it ; no inducement to publishers to produce maps, globes, pictures, reliefs, or other apparatus of the quality and in the variety to be found on the Continent; while our ordinary text-books are, as a rule, unskilful compilations by men who have no special knowledge of their subject." This neglect is attributed to the "exigencies of examination." Geography, as a class-subject, "does not pay." It is not recognised at the Universities by either professorship or readership; it does not find a real place at any of their examinations; while in the Army and Navy examinations it is at a discount ; and such geography as is given is of a very partial character, and is merely left to crammers. These unsatisfactory statements are justified by a large amount of evidence. In striking contrast to this picture is that which Mr. Keltie presents of the state of geographical education in Germany, France, Italy, Switzerland, and several other countries of Europe. Germany, as might be expected, takes the lead, and does its work most thoroughly. But the systematic study of geography is even there of recent creation. It prevails in twelve out of the twenty-one universities of Germany; and nearly all the twelve existing professorships of geography have been founded within the last twelve years. "The ideal aimed at, and being rapidly carried out, is to have one continuous course of geographical instruction from the youngest school-year up to the university." And Mr. Keltie deals with these ascending conrses, showing in detail the teaching from the elementary to the higher schools, and in the universities. His examples of lessons he himself heard at some of these schools are most graphic, and suggest their high value in any course of intelligent education.

Lord Aberdare then briefly referred to the conclusions at which Mr. Keltie arrives. These, he stated, are clear, sensible, practical, but by no means encouraging. In all these European ccuntries the curriculum is defined and imposed by the State, which, keeping the purse-strings, dictates the course of instruction. Except over our elementary schools, the State in this country exercises no such power, direct or indirect. We must be content to bring the force of public opinion to bear upon our schools and universities ; for with them, and especially with our universities, rests the solution of this great question. Mr. Keltie's Report will be duly considered by the Council ; it will doubtless be published; and means, Lord Aberdare ventured to prophesy, will be taken to bring home to our educational authorities, with fresh power and urgency, the necessity for not allowing Great Britain to lag behind our political and commercial rivals, our rivals in human culture, in the systematic study of geography. In the meantime, during the course of the autumn, an exhibition will be formed of the results of Mr. Keltie's labours in collecting specimens of the best text-books, maps, globes, diagrams, models, and other apparatus used in teaching the various branches of geography. This done, it remains for me, Lord Aberdare said, only to express the fervent hope that this latest effort of the Society to promote the studies which it was founded to extend, may meet with a large measure of success and tend to lay the basis of a sound and thoroughly national system of instruction in geography in all its branches, physical, political, and historical.

Lord Aberdare then gave a brief részmé of exploring work since his address in November last. He specially referred to the four years' explorations in Eastern Tibet of the Pundit Krishna, and to the geographical work done in connection with the Afghan Boundary Commission.

The preliminary map sent home by Major Holdich rectifies in many important points the erroneous topography in all preexisting maps, and gives us a clear idea of the surface-configuration and physical condition of one of the most interesting districts in Central Asia.
Further east the indefatigable Colonel Prjevalsky has been recently again heard of from the centre of the continent, at Lob Nor.

In and around the Zhob valley, areas of abour 5500 square miles of reconnaissance on the $\frac{1}{4}$-inch scale, and of 400 square miles of topography in the $\frac{1}{2}$-inch scale are reported to have been completed; thus going far to fill in a reproachful hiatus in our present maps of Afghanistan. The ascent of certain peaks in the Himalaya by a member of the Alpine Club, Mr. W. W. Graham, an account of which was read by him at one of the Society's meetings in June last, has attracted considerable attention in India. The classical lands of Asia Minor have again this year been the subject of topographical investigation. In the winter of $1882-3$ a fund was raised by public subscription in order to effect explorations that might throw light on the antiquities and early history of the regi $n$. Mr. W. M. Ramsay was entrusted with the execution of this scheme, and travelled with this view, May to October, I883. He invited a scholar of the American School of Athens, Mr. J. R. S. Sterrett, to accompany him during great part of the summer. During that year's work the conviction grew up that no adequate study of the history of Asia Minor was possible till the ancient topography was better known and that no advance in the study of the ancient topography could be made till a better map of the country had been compiled. It was therefore found necessary, week by week, to pay a growing attention to the natural features of the country, the natural routes of communication, and the natural boundaries separating district from district. Lord Aberdare referred to the work done in New Guinea by Mr. Van Braam Morris, Dutch Resident at Tidore, who has examined this part of the coast, and ascended the Amberno, which had always been reported by passing navigators, on account of its numerous supposed mouths, to be a large river with an extensive delta, and to the journeys. into the interior of the Rev. James Chalmers. Mr. Chalmers has visited many parts of this coast along a line of about 500 miles, and penetrated, at various places further inland, by land, than any other European, and his descriptions of the country and the habits of the vivacious, excitable, and pugnacious race of savages with which it is peopled, merit careful attention at the present time. An attempt is about to be made by the experienced traveller Mr. H. O. Forbes to penetrate to the summit of the ranges, or plateaux, which extend along the centre of this part of the great island. Since he left England on this arduous mission some weeks ago we learn that the Sydney and Melbourne branches of the Geographical Society of Australasia have offered to contribute to the expenses of this expedition, which is supported by grants by our Society, the Scottish Geographical Society, and the British Association. In other parts of Australasia the chief additions to our knowledge have been a survey of a large tract of new country in Central Queensland by Mr. C. Winnecke, and the exploration of the King Country in the northern island of New Zealand by Mr. Kerry-Nicholls, of which the explorer himself gave us an account at one of our evening meetings.

In Africa Lord Aberdare referred to the work done by Mr. H. H. Johnston at Kilimanjaro. Since then the brothers Denhardt, who had previously done excellent work in surveying the course of the River Dana, which flows from the southern slopes of Mount Kenia, have left again for East Africa, They have been commissioned, as we are informed by the German African Society, to take up a line of exploration similar to that adopted with so much success by $\mathrm{Mr}$. Joseph Thomson, but to follow it much further to the north than the point reached by our English traveller, namely, to the reported great lake Samburu, north of Lake Bahringo. Further north still the year has witnessed the'accomplishment of what may be termed one of the most interesting and difficult feats of all recent African travel. This is the journey of Messrs. F. L. and W. D. James, the authors of the well-known book on the "Wild Tribes of the Soudan," who with three English companions, Messrs. G. P. V. Aylmer, E. Lort Phillips, and J. Godfrey Thrupp, organised an expedition and started last December to cross the north-eastern angle of Africa from Berbera to Mogadoxo. The hostile disposition and uncertain temper of the Somali tribes who inhabit this wide region have hitherto offered invincible obstacles to its exploration by Europeans. Mr. James and his party, however, succeeded in penetrating 400 miles to the south, as far as Barri on the River Webbe, a point about 215 miles distant from Mogadoxo. The interior was found to be a plateau of an average elevation of about 4000 feet. 
With regard to the more southerly parts of Eastern Africa, and more especially the region between the Mozambique coast and Lake Nyassa, our knowledge has lately increased by leaps and bounds. The increase has been principally due to the systematic explorations of Mr. Consul O'Neill. 'The general remark may be permitted that, thanks chiefly to $\mathrm{Mr}$. O'Neill, we now have for the first time a fairly satisfactory knowledge of a region varied in its physical configuration, well watered, and fertile, which has hitherto remained a blank on our maps, notwithstanding the occupation of the coast by the Portuguese for nearly four centuries.

M. Giraud has returned this spring from his exploration of Lake Bangweolo and its outlet, and his unsuccessful attempt to cross Africa by way of the Upper-Congo; Mr. Arnot has crossed from Natal to the Bihé plateau by way of the Upper Zambesi Mr. Montagu Kerr has crossed Matabele-land and the Zambesi, and penetrated by a new route to the sonth-western shore of Lake Nyassa; and Mr. Richards has reached from Inhambane the southern districts of Umzila's kingdom. In Western Africa further additons have been made to our knowledge of the Congo, chiefly by the publication of Mr. Stanley's long-expected book and the map. which accompany it, and by Messrs. Grenfell and Comber's careful survey of the middle course of the Congo and the Bochini tributary to the junction of the great river Kwango.

The members of the French Expedition on the Ogowé and the northern tributaries of the Congo have also been doing good work in the survey of the territories newly acquired by France.

In South America a striking feat of exploration has been accomplished since my last address; the supposed inaccessible summit of Mount Roraima, on the confines of British Guiana and Brazil, was reached in December last by Mr. im Thurn and his companion, Mr. Perkins, accompanied by a small party of Indians.

In conclusion Lord Aberdare gave the following brief summary of the Admiralty surveys of the year 1884, for which he was indebted to the hydrographer, Capt. Wharton, R.N.: The continuous prosecutions of marine surveys in different quarters of the globe has been well maintained during the past year. The two home-surveying vessels have been employed, one on the west and the other on the east coast of Great Britain. On foreign surveys 60 officers and 500 men have been employed in four steam ships of war and five other smaller vessels. These ships have been at work in Newfoundland, the Bahama Islands, Magellan Straits, South Africa, Red Sea, Malay Peninsula, coasts of China and Korea, north-west coast of Australia, and amongst the Pacific islands. The most important additions to our hydrographical knowledge are as follows:- The survey of the Little Bahama Bank -will be shortly finished, and the same may be said of the southern shore of Newfoundland. The survey of the main strait of Magellan, to which reference was made in the last address, was completed early in the year. Many useful additions have been made to ports and salient parts of the coast of south-east Africa. In the Red Sea the intricate approaches to Sawakin have been well laid down. On the west coast of the Malay Peninsula, Penang harbour has been re-surveyed and the positions of the islands lying to the north-west and forming the eastern boundary of the ordinary route of vessels to Malacca Strait have been accurately determined. The unknown western shores of Korea, south of the approach to Seoul, for two degrees of latitude have been explored, and the main features of this island-studded shore laid down. New rivers and harbours have been entered, notably, the large river Yeun-san-gang, at the entrance to which stands the considerable town of Mokfo. There appears, however, to be little chance of immediate trade with Korea, in consequence of the absence of any valuable products and the scanty needs of the population. The southern approach to Haitan Strait on the Chinese coast, much used by British trade, has been re-charted. On the difficult shores of Western Australia such progress has been made as the small means at the disposal of the surveyors has permitted. In the Solomon Islands the Bougainville Strait has been charted. This Channel will in the future be most probably a highway for traffic between Eastern Australia and Japan. Many additions have been also made to the charts of various groups of other Pacific islands. The survey of the coasts of India carried on by officers of the Royal Navy and India Marine has been actively progressing. Surveys of Rangoon, Cheduba, and other ports in the Bay of Bengal, as well as harbours on the west coast of Hindostan, have been made. A re-survey of the great Canadian lakes has been com- menced in Georgian Bay, where trade by water is on the increase.

Lord Aberdare then intimated his resignation of the Presidency of the Society, the Marquis of Lorne having been elected to succeed him.

\section{PROF. REYNOLDS ON THE STEAM INDICATOR ${ }^{1}$}

THE object of this paper was to define the causes and extent of the disturbances in indicator diagrams. The theory, as given, had been taught for several years in Owens College; but the publication had been deferred to enable an extensive series of experiments to be made. These experiment; had now been carried out by Mr. A. W. Brightmore, stud. Inst. C.E., late Berkeley Fellow in Owens College. In the first place it was shown that there were five principal causes of disturbance, namely: the inertia of the piston of the indicator and its attached weights; the friction of the pencil on the paper, and its attached mechanism; varying action of the spring ; inertia of the drum; friction of the drum.

The effect of the inertia of the pencil and its attached mechan ism presented a mathematical problem, by the solution of which it was shown that there were two disturbances from this cause: one, a general enlargement of the mean indicated pressure, depending on the weight of the moving parts of the indicator, the stiffness of the spring, and the square of the speed. The other disturbance was a vibration of the pencil. Every indicator piston vibrated when disturbed, so that the period of vibration depended on the stiffness of the spring.

The error which these oscillations caused in the area of the diagram depended on their magnitude, and, to a greater extent, on the smailness of the number in a revolution. But the evil of these oscillations was not so much an effect on the area as in the disfigurement and the confusion they produced in the diagram. So long as there were thirty of these oscillations in a cycle, the necessary fluid friction of the indicator piston would so far reduce them as to render a fair diagram possible, but when the number was as low as ten it was all the pencil could do to prevent them upsetting the diagram.

The friction arising from the pressure of the pencil always acted to oppose the motion of the pencil, and therefore rendered it too large during expansion and exhaust and too small during compression and admission, and thus the general effect was to increase the size of the diagram. This friction consisted of that of the pencil on the paper; and that of the mechanism, caused by sustaining the pressure of the pencil. The effect of the friction of the pencil was greatly reduced by the motion of the paper. The magnitude of these effects taken together on the area of the diagram depended on the construction of the instrument and on pencil-pressure. From numerous experiments it would appear possible to make a clifference of as much as five per cent. in a locomotive in mid-gear by pencil-friction.

The couclusions, as regarded the motion of the pencil, were that the general effect of inertia and friction were both to increase the size of the diagram; that so long as the speeds were such that the number of vibrations of the pencil during a revolution of the engine was not greater than fifteen, the effect of inertia was less than one per cent., but that, if the number was greater than thirty, oscillations would show themselves unless the pencil-friction was increased. They might, by this, be kept down till the number of vibrations was equal to fifteen, but not farther, and then the necessary friction would affect the area of the diagram about five per cent. For the diagrams to be sensibly accurate, and free from oscillation, the speeds must not be greater than would make the number of vibrations equal to thirty. These speeds were given in the paper for Richards' indicators.

The effect of the inertia of the drum with an elastic cord was shown to be a nearly uniform elongation of the diagram. The result of the varying stiffness of the drum spring was a nearly uniform contraction. With Richards' indicator these two latter disturbances neutralized each other at a speed of $15^{\circ}$ revolutions per minute. Ai other speeds the effects were apparent in the length of the diagram ; but, except when the expansion was great and the connecting rod short, they did not affect the indicated pressure. The friction of the drum with an elastic cord caused the cord to be longer during the forward stroke than during the

"A Paper read at the Institution of Civil Engineers, May r9, "On the Osborne Reynolds F.R.S. 